\title{
Some Engineering Properties of Foamed Concrete for Sustainable Technological Development
}

\author{
Felix A. Oginni and Samuel N. John
}

\begin{abstract}
A study of the technology of foamed concrete production is carried out. The engineering properties and applications of this type of concrete are presented for varying densities so as to effectively tap the advantages of its use for specific purposes. The properties considered are the 7-day compressive strength, thermal conductivity, modulus of elasticity and drying shrinkage. A study of the behaviours of foamed concrete at varying dry densities for the different characteristics was undertaken. Results indicate that as the dry density increases, the engineering properties increase though at different rates for the 7-day Compressive strength, Thermal conductivity, and Modulus of elasticity. The drying shrinkage decreases as the dry density increases. A comparative study of the 7-day Compressive strength and Modulus of elasticity show that they both follow the same trend over the varying dry density except at a dry density of $1200 \mathrm{~kg} / \mathrm{m}^{3}$. A comparative study of the thermal conductivity and the percent drying shrinkage indicate that the thermal conductivity is inversely proportional to the percent drying shrinkage. Economics and other considerations together with its multipurpose applications of foamed concrete can open up business opportunities in Africa and sustainability. This can also help in providing needed funds for infrastructural development.
\end{abstract}

Index Terms - Cellular concretes, Engineering Properties, Fly ash; Foamed Concrete; Sustainable Development.

\section{INTRODUCTION - FOAMED CONCRETE TECHNOLOGY}

Concrete is a composite material composed of coarse granular material in various ratios embedded in a hard matrix of cementing or binding material which fills the space among the aggregate particles, all glued together. It plays an important role in the constructions of infrastructures and private buildings. Concrete is the only major building material that can be delivered to a project site in a plastic state and can be moulded to virtually any form or shape. It is used in constructing a wide range of civil engineering structures. There many types of concrete used in many different applications. Some common and main types of concrete are:

(i) Normal concrete;

(ii) High Strength Concrete;

(iii) High Performance Concrete;

(iv) Air Entrained Concrete;

(v) Light Weight Concrete;

(vi) Self Compacting Concrete;

(vii) Shotcrete;

(viii) Pervious Concrete;

Submitted on March 5, 2021

Published on March 31, 2021.

F. A. Oginni, Adeleke University, Ede, Nigeria

(e-mail: kafnog@gmail.com, felix.oginni@adelekeuniversity.edu.ng)

S. N. John, Faculty of Engineering and Technology, Department of Electrical \& Electronic Engineering, Nigerian Defence Academy, Nigeria

(e-mail: samuel.john@nda.edu.ng; johnsam8@hotmail.com)

\section{(ix) Roller Compacted Concrete.}

Foamed concrete is a type of porous concrete. According to its features and uses it is similar to aerated concrete. The synonyms are Aerated concrete, Lightweight concrete, and Porous concrete.

Foamed concrete, a cellular concrete was first patented in 1923, mainly for use as an insulation material. The first comprehensive review on foamed concrete was presented by Valore [1] and a detailed treatment by [2]. [3] summarised the composition, properties and uses of the cellular concrete, irrespective of the method of formation of the cell structure. An aerated concrete produced by the addition of an airentraining agent to the concrete (or a lightweight aggregate such as expanded clay aggregate or cork granules and vermiculite) is sometimes called cellular concrete, lightweight aerated concrete, variable density concrete, foamed concrete and lightweight or ultra-lightweight concrete [4], [5]. These should not be confused with aerated autoclaved concrete, which is manufactured off-site using an entirely different method. [6]-[10] have worked on different aspects of foamed concrete.

\section{MATERIALS AND PRODUCTION OF FOAMEd CONCRETE (FOAMED CONCRETE TECHNOLOGY)}

The raw materials required are:

\begin{tabular}{|c|c|}
\hline Cement & Fine Sand \\
\hline Foam & Water \\
\hline
\end{tabular}

The fine sand could be ordinary quartz sand quarry dust or industrial waste and the waste resulting from extracting and processing limestone and other rocks. The materials and the end product are presented in Fig. 1.

A mechanized production line consists of the following units:

(i) Sand dump site;

(ii) Sand conveyor belt;

(iii) Sand bin with a screw-metering device;

(iv) Cement bin with a screw-metering device;

(v) Foam generator;

(vi) Foam production plant;

(vii) Metal matrix for shaping the foamed concrete.

Sand may be conveyed through a conveyor belt into the sand bin which is equipped with a metering device for measuring the amount of sand required for a particular batch production. Cement is poured into the cement bin also equipped with a metering device. Cement is mixed with sand using water forming slurry. This is further mixed with foam produced from a foam generating machine. A typical layout of a foamed concrete plant is shown in Fig. 2. 


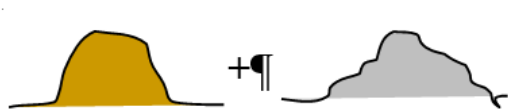

Sand
Cement

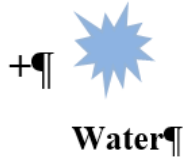

Waterq

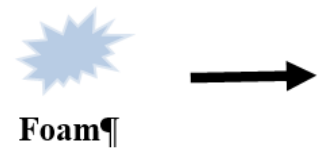

Foam

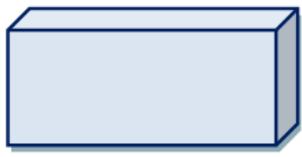

Foamed $\cdot$ Concrete $\Phi$

Fig. 1. Foamed Concrete Materials and End Product.

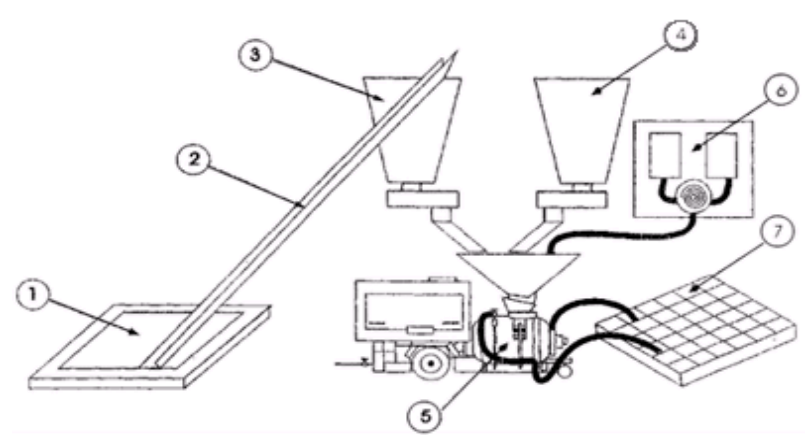

Fig. 2. Typical Layout of Foamed Concrete Production Line.

Descriptions of the labels are as indicated below:

1. A site for sand storage.

2. A sand conveyor belt.

3. A sand bin with a screw-metering device.

4. A cement bin with a screw-metering device.

5. A plant for producing foam concrete.

6. A foam generator.

7. A metal matrix (a foam concrete products shaping unit).

Stable foam is the key ingredient in the production of foamed concrete. This foam is made by a simple foaming generator where air, water and foaming chemicals are mixed and stable foam is formed. This foam can be derived from either protein or synthetic chemicals. It consists basically 95\% air and is very stable to enable it to last through the stages of mixing with the mortar slurry. The amount of foam expended can affect the cost of the concrete being produced. Generally, it takes about 400-500 liters of preformed foam to make $1 \mathrm{~m}^{3}$ of foamed (cellular) concrete (with a density range between $900-1300 \mathrm{~kg} / \mathrm{m}^{3}$ ). The various sizes of foam generator depend on the volume of foam concrete that is needed to be mixed. Plates 1 and 2 below 5 show sample of a Universal Foam Generator and Mixer respectively. The high capacity foam generator can generate e up to $600 \mathrm{l} / \mathrm{min}$. [11] has considered the use of laterite as fine aggregate in foamed concrete production. [12] has shown that Foamed concrete is the most popular of all low-density concretes in developing countries.

\section{ENGINEERING AND ECONOMIC CONSIDERATIONS FOR SUSTAINABLE DEVELOPMENT}

\section{A. Engineering Properties}

Foamed Concrete is a lightweight, free flowing concrete material, ideal for a wide range of applications. Production of this of concrete incorporates small-enclosed air bubbles within the mortar thereby making it lighter and possessing special properties such as low thermal conductivity and high fire resistance. Density of foamed concrete ranges from as low as $300 \mathrm{~kg} / \mathrm{m}^{3}$ [13] to as high as $1600 \mathrm{~kg} / \mathrm{m}^{3}$ and hence can be used in a wide range of applications from pre - cast wall blocks and panels, void filling, floor and roof screeds, roof insulation, trench reinstatement, road foundations, and bridge abutment work.

Density of regular concrete is $2400 \mathrm{~kg} / \mathrm{m}^{3}$. Although at a very low density of $300 \mathrm{~kg} / \mathrm{m}^{3}$, this material can be considered to have no structural integrity at all, it will only function as a filler or insulation use. The variable density reduces strength [14] to increase thermal, [15] and acoustical insulation by replacing the dense heavy concrete with air or a light material such as clay, cork granules and vermiculite. There are many competing products that use a foaming agent that resembles shaving cream to mix air bubbles in with the concrete. All accomplish the same outcome: to displace concrete with air. [16] determined properties of foamed concrete at different dry densities. The properties considered were:

(i) 7-day Compressive Strength

(ii) Thermal Capacity

(iii) Modulus of Elasticity and

(iv) Drying Shrinkage

Results are presented in Table I.

TABLE I: PROPERTIES OF FOAMED CONCRETE FOR DIFFERENT DRY DENSITIES

\begin{tabular}{ccccc}
\hline $\begin{array}{c}\text { Dry } \\
\text { Density } \\
\left(\mathrm{kg} / \mathrm{m}^{3}\right)\end{array}$ & $\begin{array}{c}\text { 7-day } \\
\text { Compressive } \\
\text { Strength } \\
(\mathrm{N} / \mathrm{mm} 2)\end{array}$ & $\begin{array}{c}\text { Thermal } \\
\text { Conductivity* } \\
(\mathrm{W} / \mathrm{mK})\end{array}$ & $\begin{array}{c}\text { Modulus of } \\
\text { Elasticity } \\
\left(\mathrm{kN} / \mathrm{mm}^{2}\right)\end{array}$ & $\begin{array}{c}\text { Drying } \\
\text { Shrinkage } \\
(\%)\end{array}$ \\
\hline 400 & $0.5-1.0$ & 0.10 & $0.8-1.0$ & $0.30-.35$ \\
600 & $1.0-1.5$ & 0.11 & $1.0-1.5$ & $0.22-25$ \\
800 & $1.5-2.0$ & $0.17-0.23$ & $2.0-2.5$ & $0.20-22$ \\
1000 & $2.5-3.0$ & $0.23-0.30$ & $2.5-3.0$ & $0.18-15$ \\
1200 & $4.5-5.5$ & $0.38-0.42$ & $3.5-4.0$ & $0.11-19$ \\
1400 & $6.0-8.0$ & $0.50-0.55$ & $5.0-6.0$ & $0.09-07$ \\
1600 & $7.5-10.0$ & $0.62-0.66$ & $10.0-12.0$ & $0.07-06$ \\
\hline
\end{tabular}

The average values of the engineering properties are indicated in Table II.

TABLE II: Average VALues of THE ENGINEERING PROPERTIES For VARYING DRY DENSITIES

\begin{tabular}{ccccc}
\hline $\begin{array}{c}\text { Dry } \\
\text { Density } \\
(\mathrm{kg} / \mathrm{m} 3)\end{array}$ & $\begin{array}{c}\text { 7-day } \\
\text { Compressive } \\
\text { Strength } \\
\left(\mathrm{N} / \mathrm{mm}^{2}\right)\end{array}$ & $\begin{array}{c}\text { Thermal } \\
\text { Conductivity* } \\
(\mathrm{W} / \mathrm{mK})\end{array}$ & $\begin{array}{c}\text { Modulus of } \\
\text { Elasticity } \\
\left(\mathrm{kN} / \mathrm{mm}^{2}\right)\end{array}$ & $\begin{array}{c}\text { Drying } \\
\text { Shrinka } \\
\text { ge }(\%)\end{array}$ \\
\hline 400 & 0.75 & 0.10 & 0.9 & 0.325 \\
600 & 1.25 & 0.11 & 1.25 & 0.235 \\
800 & 1.75 & 0.20 & 2.25 & 0.21 \\
1000 & 2.75 & 0.265 & 2.75 & 0.165 \\
1200 & 5.00 & 0.40 & 3.75 & 0.15 \\
1400 & 7.00 & 0.525 & 5.5 & 0.08 \\
1600 & 8.75 & 0.64 & 11.0 & 0.065 \\
\hline
\end{tabular}

The behaviours of foamed concrete at varying dry densities for different characteristics are shown in Fig. 3. As the dry density increases, the engineering properties increase though at different rates for the 7-day Compressive strength, Thermal conductivity, and Modulus of elasticity. The drying shrinkage decreases as the dry density increases. 
Fig. 4 compares the 7-day Compressive strength and Modulus of elasticity to show that they both follow the same trend over the varying dry density except at a dry density of $1200 \mathrm{~kg} / \mathrm{m}^{3}$ When Thermal conductivity and the percent drying shrinkage are compared, a different picture indicating inverse proportionality of thermal conductivity and percent drying shrinkage. This is presented in Fig. 5.

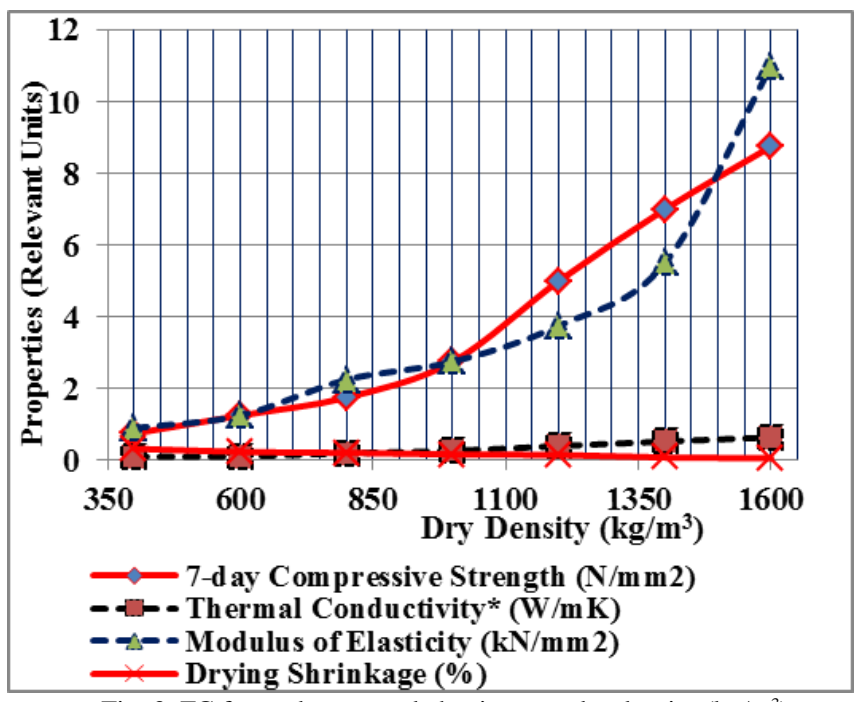

Fig. 3. FC foamed concrete behavior over dry density $\left(\mathrm{kg} / \mathrm{m}^{3}\right)$.

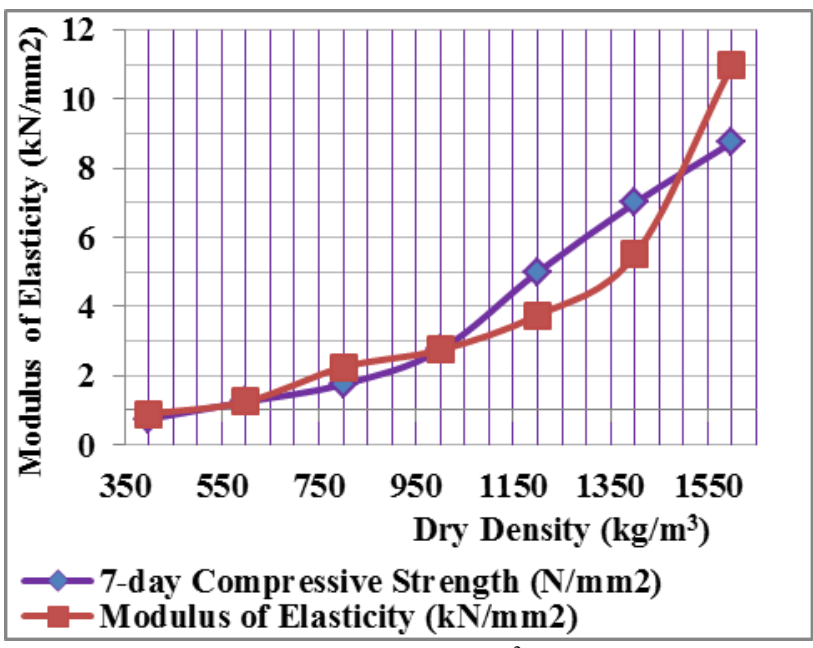

Fig. 4. 7-day Compressive strength $\left(\mathrm{N} / \mathrm{mm}^{2}\right)$ and modulus of elasticity $\left(\mathrm{kN} / \mathrm{mm}^{2}\right)$.

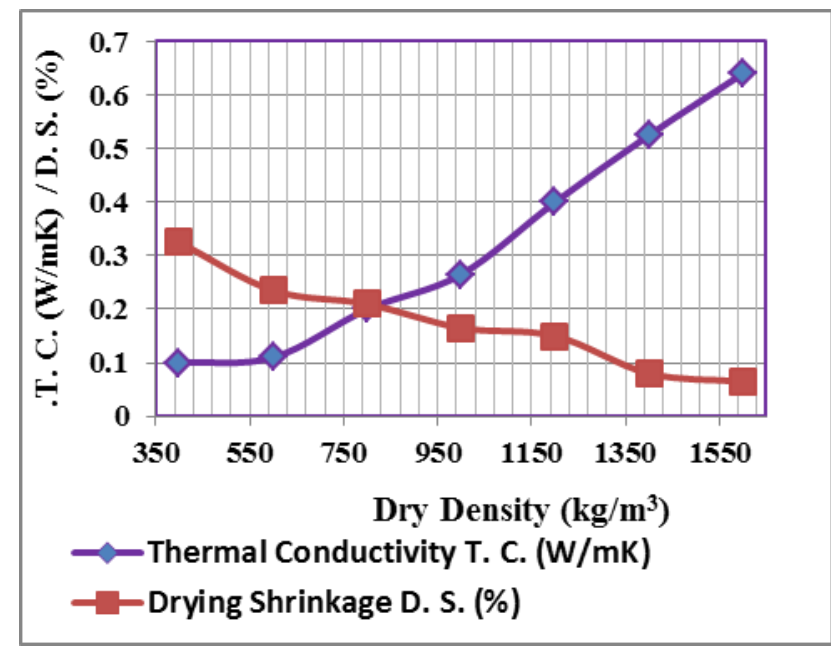

Fig. 5. Thermal conductivity, TC (W/mK) and drying shrinkage, DS (\%).

\section{B. Advantages and Economic Considerations for} Sustainability

Foamed concrete flows very well and is highly workable with no requirement for compaction. It is quick setting and can be accelerated to allow for black-topping within $4 \mathrm{~h}$. The lower density concrete with superior insulation properties has an overall lower maintenance cost. There is no sagging in any trench re-instatement activity. There is time saving with backfilling and cost effective solution.

This construction material is the most popular of all lowdensity concretes. The principal materials are readily available with low capital expenditure on equipment, implying sustainability of the technology. Foamed concrete can be produced on a small scale, even at site level, and it is relatively easy to place and finish without heavy or expensive equipment. It is self-compacting, free flowing and pumpable and, therefore, easy to place in inaccessible places. These further attest to its sustainability. It has good thermal and acoustic properties and is also frost resistant. It is however too weak for direct exposure to traffic and hail and should be protected by a wearing layer (asphalt can be used for roads).

Foam concrete can be used where fire is a risk. A test carried out by Stroy-Beton Inc. [17] also show that in addition to prolonged fire protection, the application of intense heat, such as a high energy flame held close to the surface, does not cause the concrete to spall or explode as is the case with normal dense weight concrete.

Stability of the foam is improved by the development of protein-hydrolyzation-based foaming agents and specialized foam generating equipment. This makes manufacture foamed concrete for structural applications possible.

The world experience has shown that the special technological feature of foamed concrete allows it to be used for multipurpose applications as indicated below:

- Well backfilling, cavity filling,

- Masonry grouting;

- Production of building blocks and wall panels;

- Ground Stabilization;

- Leveling Floors;

- Monolithic low-rise and individual house building;

- Setting up pipeline monolithic thermal insulation;

- Thermal and soundproofing insulation of floors;

- Thermal insulation of flat, mono- and double-pitch roofs;

- Road Sub-Bases and maintenance;

- Bridge Abutments and repairs.

\section{Global Use of FoAmed CONCRETE}

Various areas of applications have made foamed concrete, to be used in more than 50 countries of the world, [10]. It is being used for level corrections in housing developments, as a fill material where ground subsidence has taken place and as a founding layer for road works on very weak soils in The Netherlands and many other parts of the world. Foamed concrete is used as structural materials in schools, apartments and housing developments in countries such as Brazil, Singapore, Kuwait, Nigeria, Botswana, Mexico, Indonesia, Libya, Saudi Arabia, Algeria, Iraq and Egypt [10]. These are developing economies. The global 
experience indicates its sustainability.

\section{CONCLUSIONS AND RECOMMENDATIONS}

The behaviours of foamed concrete at varying dry densities for the different characteristics can be exploited and applied for specific advantageous use. It has been concluded that as the dry density of foamed concrete increases, the engineering properties increase though at different rates for the 7-day Compressive strength, Thermal conductivity, and Modulus of elasticity. On the other hand, the drying shrinkage decreases as the dry density increases. Conclusion from the comparative study of the 7-day Compressive strength and Modulus of elasticity has shown that they both follow the same trend over the varying foam concrete dry density except at a dry density of $1200 \mathrm{~kg} / \mathrm{m}^{3}$. There is the need to carry out further work in this direction. More tests should be undertaken for other concrete properties to determine their responses to the varying foam concrete dry densities.

From this study, there is an indication that the thermal conductivity is inversely proportional to the percent drying shrinkage. More work should be done to further re-establish this relationship.

The world experience has shown that the special technological feature of foamed concrete allows it to be used for multipurpose applications in the building and other infrastructural developments industries as highlighted in the text. This can be used to its advantage in Africa and other developing nations for sustainable infrastructural development.

\section{ACKNOWLEDGEMENTS}

We are very grateful to Osun State University, Oshogbo, Nigeria and Covenant University, Canaanland, Ota, Nigeria for the use of space and facilities while carrying out this study.

\section{REFERENCES}

[1] Durack J. M and L.Weiqing, (1998): The properties of foamed air cured fly ash based concrete for masonry production. In: Page.

[2] A, Dhanasekar M, Lawrence S, editors. Proceedings of the Fifth Australasian Masonry Conference, 1998, Gladstone, The Queensland, Australia. p. 129-38.

[3] Eden N.B., Manthrope A. R., Miell S. A., Szymanek P. H and, K. L. Watson, (1980): Autoclaved aerated concrete from slate waste, Part 1Some property/density relationships. Int J Lightweight Concr 1980;2:95-100

[4] Falade F. The Potential of Laterite as Fine Aggregate in Foamed Concrete Production. Civil and Environmental Research, Vol.3, No.10, 2013, www.iiste.org ISSN 2224-5790 (Paper) I 2225-0514 (Online).

[5] Kearsley, E. P. and H. F. Mostert, (1997): Foamcrete in Developing Communities, Proceedings FIP Symposium 1997: The Concrete Way to Development, Johannesburg, South Africa, March 1997.

[6] The Concrete Society of Southern Africa, 1997, pp. 735 - 745.

[7] Lushiku, M. D. and E. P. Kearsley (2004): The effect of material composition on the properties of dry shotcrete. Journal of the South African Institute of Civil Engineering, Volume 46 (2) 2004 pp. 2-8.

[8] Oginni, F. A., 2014: Continental Application of Foamed Concrete Technology: Lessons for Infrastructural Development in Africa. British Journal of Applied Science \& Technology 5(4): 417-424, 2015, Article no. BJAST.2015.040 ISSN: 2231-0843. SCIENCEDOMAIN international www.sciencedomain.org.
[9] Pospisil F, Jambor J, and J. Belko, (1992): Unit weight reduction of y ash aerated concrete. In: Wittmann FH, editor. Advances in Autoclaved Aerated Concrete. A.A. Balkema, 1992. p. 43-52.

[10] Potgieter, J. H., Potgieter, S. S., Loubser, M., Kearsley, E. P., Strydom, C. A., de Waal, D. and S. Paul (2003): The use of Fly Ash to Treat Waste from the Ferro-alloy Industries. Proceedings of the 11th International Conference on the Chemistry of Cement, May 2003, Durban South Africa, pp. 2148-2155.

[11] Puttappa CG, Rudresh V, Ibrahim A, Muthu KU, Raghavendra HS Mechanical Properties of Foamed Concrete. International Conference on Construction and Building Technology, ICCBT 2008 - A - (43) pp. 491-500.

[12] Ramamurthy K and N. Narayanan, (1999): Influence of fly ash on the properties of aerated concrete. In: Proceedings of the International Conference on Waste as Secondary Sources of Building Materials. New Delhi: BMTPC, 1999. p. 276-82.

[13] Rudnai, G. (1963): Lightweight concretes, Budapest: Akademiai Kiado. Short A and W. Kinniburgh (1963): Light weight concretes. Asia Publishing House, 1963.

[14] The Concrete Institute, (2013): Foamed Concrete. Published by the Concrete Institute, Midrand, 2013 (C) the concrete institute P. O. Box 168, Halfway House, 1685 Block D, Lone Creek, Waterfall Park, Bekker Road, Midrand T 0113150300 • F 0113150315.

[15] Valore RC. (1954). Cellular concrete part 1 composition and methods of production, ACI j ;50:773-96.

[16] Watson K. L., Eden N. B. and J. R. Farrant, (1977): Autoclaved aerated materials from slate powder and portland cement. Precast Concr 1977:81-5.

[17] Watson K. L. (1980): Autoclaved aerated concrete from slate waste, Part 2 - Some property/porosity relationships. Int J Lightweight Concr 1980;3:121-3.

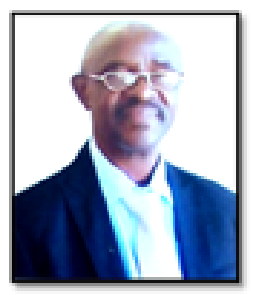

\section{Oginni Felix Adeniran}

Associate Professor, BSc (Agric. Engr.), PhD. Civil Engineering, Postgraduate Diploma, Management Studies.

COREN, FNICE, FNSE, FIIA, FIPMD

Felix Adeniran OGINNI was born in Ilesha, Osun State, Nigeria on the 20th January, 1949. He had First degree in 1975 at University of Ife, Ile-Ife, now Obafemi Awolowo University, Ile-Ife Nigeria. His $\mathrm{PhD}$ was obtained in 1982 from University of Southampton, Southampton, UK. In the same 1982, he obtained a Postgraduate Diploma in Management Studies from Portsmouth Polytechnic, Portsmouth, UK. He is a Practicing Civil Engineer with specialization in Water Resources Engineering, Hydraulics, Flood, Erosion Control, Drainage, Irrigation and Environmental Engineering.

In consulting and field investigation works, he was in Osot Associates, Consulting Civil Engineers, 1978 - 1990, and became Partner, 1985. He was Team Leader, Hydrographic Survey of $348 \mathrm{~km}$ River Rima Training works, 1983/84. In 1990 he came in as Principal Partner (Nigeria), DECS Associates Engineers and Builders. He was Chief Executive Officer, CEO, and now Chairman, Kafnog Limited, a Construction Company, since 1993. $\mathrm{He}$ is the Technical Director, AlphaPride Limited, a Design, Cost Management and Civil / Building Construction Company.

In lecture rooms, Felix was Adjunct Lecturer, Civil Engineering Departments, The Polytechnics, Ibadan, 1977-1979 and University of AdoEkiti, Undergraduate/Postgraduate 2003-2008. He was in Igbinedion University, Okada-Benin, 2005-2007; Covenant University, Ota, 20072010, Osun State University, Oshogbo, 2010-2019, and Adeleke University, Ede, 2019 - to date. He has been Civil Engineering Departmental Head in Igbinedion University, Covenant University, Osun State University, and now also in Adeleke University, Ede, all in Nigeria. He had been External Examiner, Civil Engineering Department of The Polytechnics, Ibadan, 1977-1979 and LAUTECH, Ogbomosho, Nigeria, 2015/2016 sessions. He was also External Examiner to Postgraduate Schools of LAUTECH and University of Ibadan, UI, Nigeria.

Professionally, He became Chattered Engineer, 1984; Fellow, Nigerian Institution of Civil Engineers, NICE, 2012; Fellow, Nigerian Society of Engineers (NSE), 2014; Fellow Institute of Industrial Administration, Nigeria (FIIA), 2014; Fellow, Institute of Policy Management Development, Membership No. 1209, (FIPMD), 2019; and had Special Award for Excellence in Research and Administration, 2013. He was Chairman, LOC, Oshogbo 2012 AGM of NICE. He was Pioneer Chief Examiner, Oshogbo Examination Center for NSE, and a Member, Technical Program Committee, International Conference on Environmental Engineering and Pollution Technology, Phuket Island, Thailand. Oginni is listed in the Maiden Edition, 2016, Who is Who in Civil Engineering in Nigeria. 


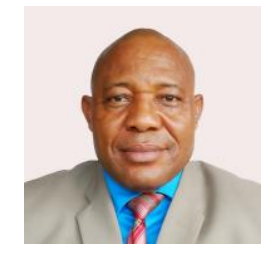

John Samuel Ndueso

Professor, BSc (Engr.), MSc, MPhil., Ph.D.

MNSE, MIET, MCP, COREN

Samuel Ndueso John was born at Nung-Ukim, Akwa Ibom State, Nigeria on the 13th April 1967.

He had his higher education at Donetsk National Technical University where he successfully defended and obtained B.Sc, M.SC, MPhil and Ph.D. degrees in Computer Systems and Network Engineering, specializing in Computer Science, Computing Machines, Complex Systems, Networks and security in 1993, 1994, 2000 and 2005, respectively.

$\mathrm{He}$ is a Professor of Computer Systems and Network Engineering in the Department of Electrical and Electronic Engineering, Faculty of Engineering and Technology, Nigerian Defence Academy, Kaduna, Kaduna State, Nigeria, and a member of the University Senate. He is a visiting professor to the University of Maiduguri, Borno State. He is an EXTERNAL EXAMINER to the Department of Computer Science, NorthWest University, Mafikeng Campus, South Africa and other Nigerian Universities.

He has published more than hundred (100) several scholarly researched articles in reputable journals, conference proceedings and presented papers at international conferences, workshops, and seminars on diverse topics in areas including Computer Systems, Computer Security, Computational Intelligence, Computational Science, and Network Engineering. Over his more than twenty two (22) years of career as a LECTURER, he had developed a skill set directly relevant to the Lecturing role in the area of Computer Systems Engineering including Computer Science, Computing Machines, Complex Systems, Networks, and Cyber Security Expertise.

His research interest involves the recent research trends of data efficiency and Security Issues globally: Efficient Data Exchange in Computer Networks: Big Data and Security in an Emerging Smart World; Monitoring of Soldier Health, Safety and Performance using Wearable Sensor Networks; Mobile Phone Stunning System for Identifying Kidnapper Location; Adaptive Fuzzy Morphology for an Enhanced Image Noise Reduction on a Smart Database; Neuro-Fuzzy Model for Intelligent Last Mile Routing; Cybersecurity, Cybercrime and Forensic. He has successfully supervised undergraduate and postgraduate students.

Prof. John is a corporate member of the Nigerian Society of Engineers (MNSE), Member, the prestigious Institution of Engineering and Technology (MIET), United Kingdom (UK) and a registered Computer Engineer with the Council for the Regulation of Engineering in Nigeria (COREN). 